Article

\title{
Performance-Related Assessment of the Potential Use of Sawing Sludge in Cementitious Fluidized Thermal Backfills
}

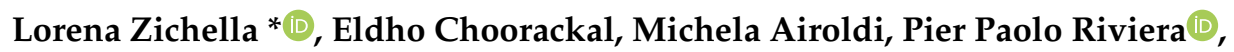 \\ Rossana Bellopede $\mathbb{D}$ and Ezio Santagata $\mathbb{D}$ \\ Department of Environment, Land and Infrastructure Engineering (DIATI), Politecnico di Torino, 10129 Turin, \\ Italy; eldho.choorackal@polito.it (E.C.); michelaairoldi00@gmail.com (M.A.); pierpaolo.riviera@polito.it (P.P.R.); \\ rossana.bellopede@polito.it (R.B.); ezio.santagata@polito.it (E.S.) \\ * Correspondence: lorena.zichella@polito.it
}

Received: 5 November 2020; Accepted: 19 November 2020; Published: 20 November 2020

Featured Application: The research work presented in this paper may be of value for the management of sawing sludge in the context of a circular economy approach. Potential applications may occur in all modern infrastructures in which high-voltage cables are buried in the pavement subgrade.

\begin{abstract}
The management of sawing sludge originated from cutting operations of ornamental stones represents a challenging task as a consequence of its peculiar composition that includes non-negligible amounts of heavy metals resulting from the wear and tear of cutting tools. The aim of the research work presented in this paper was to investigate the feasibility of using these by-products as supplementary constituents of cementitious mixtures employed for the formation of Fluidized Thermal Backfills (FTB). These mixtures are designed and produced for filling operations in pavement subgrades in which high-voltage electrical transmission cables are buried for protection purposes. Two different types of sawing sludge were thoroughly analyzed from a physical and chemical point of view and thereafter employed for the laboratory production of four FTB mixtures. Then, these were subjected to thermal, mechanical, and environmental tests in order to verify their suitability for their intended use. All investigated FTB mixtures exhibited a satisfactory and stable thermal conductivity, and they also displayed enhanced stiffness properties in comparison to standard subgrade and sub-base materials. Controversial results were obtained with respect to environmental properties resulting from leaching tests, thus suggesting that further investigations are needed before any full-scale application can take place.
\end{abstract}

Keywords: circular economy; sawing sludge; Fluidized Thermal Backfill (FTB); buried electrical cables; thermal conductivity; resilient modulus; leaching test

\section{Introduction}

The construction of road infrastructures often entails the installment of utility lines which in most cases, for protection purposes, are buried in the pavement subgrade. High-voltage transmission cables are among these utility lines, and their ampacity depends upon the temperature they reach during power transmission. In fact, these cables are designed to transfer power at maximum current carrying capacity [1], thereby generating heat as a function of the thermal properties of the surrounding subgrade material. If such a material does not dissipate heat effectively, temperature of the cables may exceed the optimum operation value $\left(65-70^{\circ} \mathrm{C}\right)$ and may consequently compromise their service 
life [2]. The resulting scenario can be catastrophic in the sense that repair operation may require, in addition to cable substitution, demolition and reconstruction of the entire pavement.

As a result of the heat-related issues outlined above, in the presence of high-voltage cables, in the formation of subgrade fills, use can be made of specifically designed composite materials known as "thermal backfills". These materials exhibit a sufficiently high thermal conductivity that enhances heat dissipation from buried cables and consequently reduces their core temperature [1-4]. Thermal backfills are also designed to maintain their properties as stable in time, thereby limiting the effects of the progressive creation of dry zones near the cables, as in the case of typical subgrade soils, which can lead to a significant decrease of conductivity and to the reduction of cable rating [4-7].

In some cases, depending upon design requirements and construction constraints, thermal backfills can be conceived and produced in the form of Fluidized Thermal Backfills (FTBs). Such a category of materials includes self-compacting and self-leveling flowable mixes, which are ideal for applications in tight and challenging geometrical configurations where laying and compaction operations may be especially complex. FTBs are constituted by hydraulic binder (i.e., cement), aggregates, water, and chemical admixtures; however, several recycled components can be included in their composition, with a corresponding reduction of production costs and environmental impact [4,8-16].

Different factors affect the thermal properties of cementitious backfilling materials. Kim et al. [17] found that the volume of aggregate fractions and moisture content affected the conductivity of backfilling mixtures, although non-negligible effects were also attributed to chemical admixture type and cement dosage. Uysal et al. [18] and Damdelen [19] observed that thermal conductivity was affected by cement dosage and type, water-to-cement (W/C) ratio, mix density, and mineralogical structure of aggregates. Célestin et al. [11] pointed out that composition parameters such as W/C ratio, cement type, and dosage had the main effects on thermal properties, while a lower influence was attributed to the mineralogical nature of aggregates. Nevertheless, they observed that the conductivity of backfilling mixtures was improved in the presence of increasing values of quartz content. Finally, while investigating the thermal properties of FTB mixtures, Choorackal et al. [14] reported the negligible effects due to curing time, whereas they underlined the fundamental role played by cement content, $\mathrm{W} / \mathrm{C}$ ratio, and aggregate type.

The study described in this paper focused on the characterization of FTBs that were specifically designed to achieve satisfactory thermal and mechanical properties. However, as described in detail in the following, the main goal of the investigation was to assess the feasibility of using sawing sludge in their production.

Sawing sludge is generated by cutting operations that are performed during the processing of ornamental stones. Depending upon the mineralogical composition of the original stone, these operations rely upon the use of different techniques and tools (gangsaw, diamond blade, diamond wire). Residual sludge is classified as inert waste (EWC code 010413) and is normally sent to landfill disposal. However, as a result of the very large quantities produced every year (5 million tons in the EU according to Graziani et al. [20] and Zichella et al. [21]), the management of residual sawing sludge represents an unsolved environmental and economic issue. In such a context, its recycling as a secondary raw material is a challenging task as a consequence of its very fine particle size distribution and high water content. Furthermore, the presence of heavy metals deriving from wear and tear of cutting tools [14,22-24] usually prevents its direct reuse without any preliminary treatment or processing.

Several studies have tried to identify potential industrial applications in which sawing sludge may be employed, mainly by considering its inclusion in construction and building materials. Al-Hamaiedeh et al. [25] analyzed the effect of adding different amounts of granite sludge powder in cement mortar and concrete, thereby observing an increase of setting time and compressive strength. Similar studies were performed by Amin et al. [26] and Mashaly et al. [27], who investigated the feasibility of using granite sludge as a supplementary component in cement mortar and concrete. These researchers showed that the addition of granite sludge resulted in a negligible reduction of 
the mechanical properties when the employed percentage did not exceed $20 \%$ by weight of the total aggregates. The positive effects of using granite by-products in the production of mortar and concrete were also discussed by Singh et al. [28,29]. da Silva et al. [30] found that the replacement of fine aggregates with granite powder in mortar resulted in a lower depth of carbonation, thus leading to an increase of durability. Finally, the use of marble powder waste was found to be effective also in asphalt layers and in controlled low-strength materials by Santagata et al. [31], Aydin et al. [32], and Choorackal et al. $[13,14]$.

The experimental investigation described in this paper entailed the performance-related characterization of laboratory-prepared FTBs containing sawing sludge generated from the cutting and processing of different types of rock blocks. As discussed in the following, measured properties included thermal conductivity and resilient modulus. Additional tests of environmental relevance were also carried out to assess the contents of heavy metals in the mixtures and those resulting from leaching tests.

It should be underlined that the use of sawing sludge in FTB mixtures was envisioned in the absence of any preliminary processing or treatment. Such an approach was considered to be consistent with the circular economy philosophy encouraged by the current strategies the prevention and recycling of waste of the European Commission. Furthermore, it tries to meet the needs of the construction industry that is constantly striving in the attempt of matching the production of high-quality materials with a corresponding containment of costs.

\section{Materials and Methods}

\subsection{Constituent Materials}

FTB mixtures were prepared in the laboratory by employing two quartzite aggregate fractions (0-8 $\mathrm{mm}$ and 8-14 mm), two different types of sawing sludge (indicated as " $\mathrm{A}$ " and "B"), CEMII/A-L R42.5 cement [33], water, and a polycarboxylate-based superplasticizer.

According to the information obtained from the supplier, both aggregate fractions were reported to have a quartz content of the order of $95 \%$. They were selected to form the bulk structure of the FTB mixtures, since quartzite is the metamorphic rock with the highest thermal conductivity [34,35]. The two types of sludge were retrieved from cutting plants located in the north-west of Italy, where they were being stockpiled before disposal. General information on the origin, composition, and generating cutting technology of the two types of sludge is listed in Table 1.

Table 1. General information on sawing sludge.

\begin{tabular}{cccc}
\hline Sludge Type & Stone Type & Composition & Cutting Technology \\
\hline A & Serizzo stone & $\begin{array}{c}\text { Quartz, plagioclase, } \\
\text { orthoclase, biotite, } \\
\text { muscovite, epidote }\end{array}$ & Gangsaw \\
& Mix of silicate stones & $\begin{array}{c}\text { Quartz, plagioclase, } \\
\text { orthoclase, alkaline } \\
\text { feldspar, biotite, } \\
\text { Buscovite, pyroxene, } \\
\text { white mica, chlorite }\end{array}$ & $\begin{array}{c}\text { Miscellaneous (gangsaw, } \\
\text { diamond blade, } \\
\text { diamond wire) }\end{array}$ \\
& (Beola, Granite, Serizzo, \\
Luserna, Syenite) & & \\
\hline
\end{tabular}

Preliminary analysis of aggregate fractions and sludge included the determination of particle size distribution and specific gravity (SG) as per corresponding EN standards [36,37].

The quartz content of the investigated sludge types was assessed by subdividing them into several size fractions $(>0.425 \mathrm{~mm}, 0.425 \div 0.212 \mathrm{~mm}, 0.212 \div 0.106 \mathrm{~mm}, 0.106 \div 0.075 \mathrm{~mm}, 0.075 \div$ $0.038 \mathrm{~mm},<0.038 \mathrm{~mm}$ ) and by consequently performing petrographic observations by means of an optical microscope (Leika DMLP). Quantitative quartz content data were obtained by employing an image analysis software (ImageJ) for the processing of the microscope outputs. 
Since contamination from heavy metals was expected due to the wear and tear of cutting tools, sludge was subjected to chemical analyses and leaching tests. Chemical analyses were performed on dried samples of sludge by means of an inductively coupled plasma (ICP) mass analyzer (as per [38]). Then, test samples were subjected to leaching tests carried out in accordance with EN 12457-2 [39], with the consequent determination of the heavy metals content of the leachate solution by means of the previously mentioned ICP mass analyzer.

Finally, a supplementary quick assessment of the quantity of metals present in the two types of sludge was performed by following the procedure described in Zichella et al. [24], which was based on the use of a Kolm-type high-gradient magnetic separator.

Results obtained in this preliminary characterization phase of constituent materials are displayed in Figure 1 and in Tables 2-6.

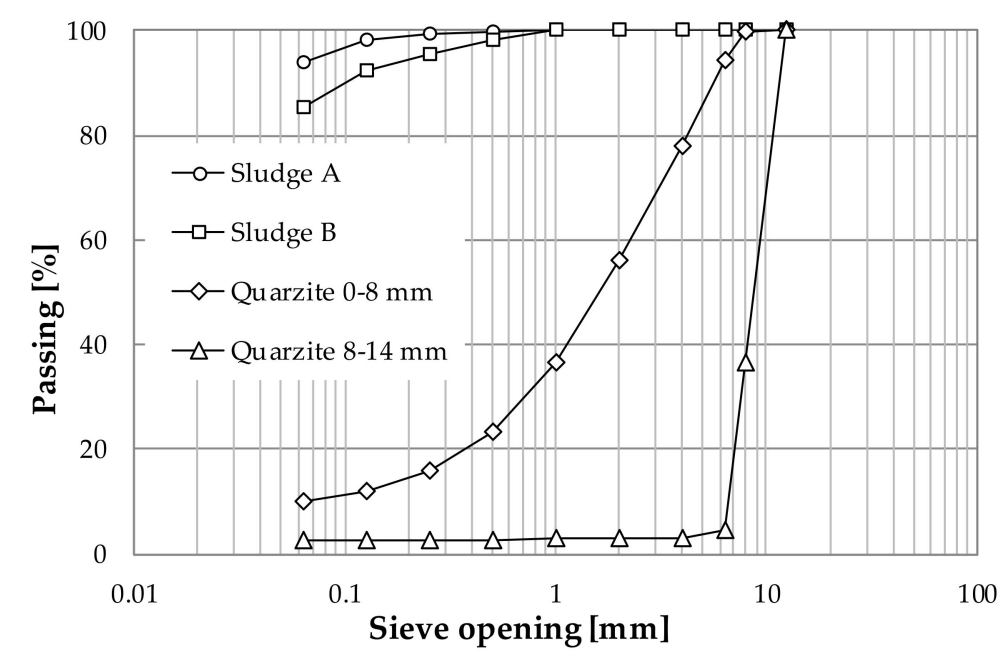

Figure 1. Particle size distribution of aggregate fractions and sawing sludge.

Table 2. Specific gravity of aggregate fractions and sawing sludge.

\begin{tabular}{cc}
\hline Fractions & SG \\
\hline $0-8 \mathrm{~mm}$ & 2.79 \\
$8-14 \mathrm{~mm}$ & 2.72 \\
Sludge A & 2.67 \\
Sludge B & 2.74 \\
\hline
\end{tabular}

Table 3. Quartz content of sawing sludge (values in percent).

\begin{tabular}{|c|c|c|c|c|c|c|}
\hline \multirow{2}{*}{ Sludge Type } & \multicolumn{6}{|c|}{ Fractions [mm] } \\
\hline & $>0.425$ & $0.425 \div 0.212$ & $0.212 \div 0.106$ & $0.106 \div 0.075$ & $0.075 \div 0.038$ & $<0.038$ \\
\hline $\mathrm{A}$ & 5 & 10 & 25 & 9 & 11 & 43 \\
\hline $\mathrm{B}$ & 35 & 45 & 35 & 8 & 22 & 52 \\
\hline
\end{tabular}

Table 4. Chemical composition of sawing sludge (threshold limits defined in [40], values in $\mathrm{mg} / \mathrm{kg}$ ).

\begin{tabular}{cccccccccccc}
\hline Sludge Type & $\mathbf{B a}$ & $\mathbf{C u}$ & $\mathbf{Z n}$ & $\mathbf{C o}$ & $\mathbf{N i}$ & $\mathbf{V}$ & $\mathbf{C d}$ & $\mathbf{C r}_{\text {tot }}$ & $\mathbf{C r V I}$ & $\mathbf{P b}$ & $\mathbf{F e}$ \\
\hline A & 68 & 186 & 54.5 & 10.4 & 86.5 & 25.6 & $<1$ & 130 & $<5$ & 4.7 & 34.28 \\
B & 72 & 108 & 125 & 102 & 15 & 22 & $<1$ & 1836 & $<5$ & 26 & 11.84 \\
\hline Threshold limits for reuse & - & 600 & 1000 & 250 & 500 & - & 15 & 800 & 15 & 1000 & - \\
\hline
\end{tabular}


Table 5. Results of leaching tests performed on sawing sludge (threshold limits defined in [41]).

\begin{tabular}{cccccccccccc}
\hline \multirow{2}{*}{ Sludge Type } & $\mathbf{B a}$ & $\mathbf{C u}$ & $\mathbf{Z n}$ & $\mathbf{C o}$ & $\mathbf{N i}$ & $\mathbf{V}$ & $\mathbf{C d}$ & $\mathrm{Cr}_{\text {tot }}$ & $\mathbf{C r V I}$ & $\mathbf{P b}$ & $\mathbf{F e}$ \\
\cline { 2 - 12 } & {$[\mathrm{mg} / \mathrm{L}]$} & {$[\mathrm{mg} / \mathrm{L}]$} & {$[\mathrm{mg} / \mathrm{L}]$} & {$[\mathrm{g} / \mathrm{L}]$} & {$[\mathrm{g} / \mathrm{L}]$} & {$[\mathrm{g} / \mathrm{L}]$} & {$[\mathrm{g} / \mathrm{L}]$} & {$[\mathrm{g} / \mathrm{L}]$} & {$[\mathrm{g} / \mathrm{L}]$} & {$[\mathrm{g} / \mathrm{L}]$} & {$[\mathrm{mg} / \mathrm{L}]$} \\
\hline A & $<0.01$ & $<0.001$ & $<0.001$ & 4.49 & $<1$ & 5.48 & $<1$ & $<1$ & $<0.01$ & $<1$ & 0.03 \\
B & 0.02 & 0.01 & 0.01 & $<1$ & 10 & 3.36 & $<1$ & 2.45 & $<0.01$ & $<1$ & 4.48 \\
Threshold limits for reuse & 1 & 0.05 & 3 & 250 & 10 & 250 & 5 & 50 & - & 50 & - \\
\hline
\end{tabular}

Table 6. Results of magnetic separation tests.

\begin{tabular}{ccc}
\hline \multirow{2}{*}{ Sludge Type } & \multicolumn{2}{c}{ Fraction [\%] } \\
\cline { 2 - 3 } & Magnetic & Non-Magnetic \\
\hline A & 3.0 & 97.0 \\
B & 2.5 & 97.5 \\
\hline
\end{tabular}

As shown in Figure 1, it was observed that both types of sludge were characterized by a very fine particle size distribution, which qualifies them as good candidates for inclusion in FTBs. In fact, in order for FTBs to exhibit a self-compacting and self-leveling behavior, it is necessary to include in their formulation a relevant amount of fines [15].

Test results contained in Table 2 indicate that the SG determined for the quartzite fractions was consistent with data reported in literature, which refer to a typical range of $2.6 \div 2.8$ [42]. However, significant differences were recorded when comparing the SG values of the two types of sludge, thus confirming their different origin in terms of mineralogical composition and cutting operations.

With respect to composition (Table 3), it was found that sludge B contained a greater amount of quartz in comparison to sludge A. This is a consequence of the different quartz content of the rocks from which they were derived: of the order of $50 \%$ for silicate rocks (that yielded sludge B) and of approximately $20 \%$ for Serizzo stone (corresponding to sludge A).

The significant difference in the composition and origin of the two types of sludge were also reflected by the results of chemical analyses and leaching tests (Tables 4 and 5, respectively) that focused on the presence of heavy metals.

As indicated in Table 4, sludge A showed higher contents of $\mathrm{Ni}, \mathrm{Cu}$, and $\mathrm{Fe}$, which come from employed gangsaw cutting tools, while sludge B was characterized by higher contents of $\mathrm{Zn}$, $\mathrm{Co}, \mathrm{Pb}$, and $\mathrm{Cr}_{\text {tot }}$, which was probably as a consequence of the diamond blade and diamond wire technologies used during processing operations. By comparing the concentration of heavy metals of both materials with the threshold limits established by Italian legislation for use in industrial and commercial areas $[38,40,43]$, it was observed that only the concentration of $\mathrm{Cr}_{\text {tot }}$ of sludge $\mathrm{B}$ exceeded the prescribed limit. In any case, it should be underlined that the above-mentioned legal limits refer to the use of materials in their raw form, which is not the case of the sludge considered in the study described in this paper.

As expected, results obtained from leaching tests (Table 5) were not fully consistent with those of the analyses discussed above. This is due to the specific phenomena that occur during sludge-water interaction and to the subsequent release of compounds containing heavy metals. As shown in Table 5, experimental data were compared to the maximum concentration limits established by the Italian Ministerial Decree 186/2006 [41]. When these limits are not violated, as in the case of both considered sludge samples, according to the current legislation the material can be reused as a secondary raw material. If any of the listed limits is violated, the tested material is considered to be potentially harmful with respect to pollution of water courses and reservoirs and therefore requires being treated as a special non-hazardous waste to be disposed of in specifically authorized landfills.

The results of magnetic separation tests, as reported in Table 6, revealed that in terms of their percentage of magnetic fraction, the two sludge samples were quite similar, with values of the order of $2.5 \div 3.0 \%$. 


\subsection{FTB Mixtures}

FTB mixtures were designed by following the mix-design procedure proposed by Choorackal et al. [15]. The target size distribution was that proposed by Funk et al. [44] as indicated in Equation (1):

$$
(D)=100 \cdot \frac{D^{q}-D_{\text {min }}^{q}}{D_{\text {max }}^{q}-D_{\text {min }}^{q}}
$$

where $\mathrm{D}$ is the diameter of aggregate particles (in $\mathrm{mm}$ ), $\mathrm{P}(\mathrm{D})$ - expressed in \%-represents the cumulative percentage passing the sieve with opening equal to $D, D_{\max }$ is the maximum diameter of aggregate particles in the mixture (in $\mathrm{mm}$, fixed at 12.5 for all mixtures and corresponding to a $\mathrm{P}(\mathrm{D})$ equal to $100 \%$ ), $D_{\min }$ is the minimum diameter of aggregate particles in the mixture (in mm, assumed to be equal to $5 \mu \mathrm{m}$ for all mixtures), and $\mathrm{q}$ is the so-called distribution modulus (which defines the balance of coarse and fine aggregates within the aggregate skeleton). Based on the past experiences of the authors [13-16], q was set equal to 0.21 .

The composition of the FTB mixtures included in the investigation is reported in Table 7, in which they are associated to as alphanumeric identification code given by the combination of sludge type (A or B), cement content (equal $50 \mathrm{~kg} / \mathrm{m}^{3}$ or $100 \mathrm{~kg} / \mathrm{m}^{3}$ ), and water-to-powder ratio (W/P, equal to 0.75 or 0.85$)$. Cement contents, expressed with respect to the total volume of the mixtures, were chosen in the typical range employed for FTBs, which are not required to reach very high strength values after curing. W/P values were those considered to be optimal in order to achieve a satisfactory degree of fluidity in combination with the employed superplasticizer (the dosages of which are expressed as a percentage by weight of cement). It is worth noting that the term "powder" is herein used to collectively indicate cement and sludge, which jointly contribute to cement paste fluidity and void filling. Percentages of the various granular components (sludge and quartzite fractions) are expressed by weight and are referred to the overall load-bearing aggregate skeleton.

Table 7. Composition of investigated Fluidized Thermal Backfills (FTB) mixtures.

\begin{tabular}{|c|c|c|c|c|c|c|c|}
\hline \multirow[b]{2}{*}{ FTB Mixture } & \multirow{2}{*}{$\begin{array}{l}\text { Cement } \\
{\left[\mathrm{kg} / \mathrm{m}^{3}\right]}\end{array}$} & \multirow[b]{2}{*}{$\mathbf{W} / \mathbf{P}[-]$} & \multirow{2}{*}{$\begin{array}{c}\text { Superplasticizer } \\
{[\%]}\end{array}$} & \multicolumn{4}{|c|}{ Composition of Aggregate Skeleton [\%] } \\
\hline & & & & Sludge A & Sludge B & $\begin{array}{l}\text { Quartzite } \\
0-8 \mathrm{~mm}\end{array}$ & $\begin{array}{l}\text { Quartzite } \\
\text { 8-14 mm }\end{array}$ \\
\hline A-C50-0.85 & 50 & 0.85 & 0.25 & 18 & - & 71 & 11 \\
\hline A-C100-0.75 & 100 & 0.75 & 0.50 & 18 & - & 71 & 11 \\
\hline B-C50-0.75 & 50 & 0.75 & 0.25 & - & 19 & 69 & 12 \\
\hline B-C100-0.75 & 100 & 0.75 & 0.50 & . & 19 & 69 & 12 \\
\hline
\end{tabular}

All mixtures were prepared by means of a portable mortar mixer by adopting a protocol that entailed a preliminary mixing of dry quartzite fractions, sludge, and cement, which was followed by the addition of a premixed solution of water and superplasticizer additive. The resulting blend of components was continuously mixed until the achievement of a homogeneous material. Then, test specimens were prepared by employing plastic cylinders in which the mixtures were poured and thereafter allowed to settle with no application of compacting action.

\subsection{Test Methods}

Thermal conductivity of the four candidate FTB mixtures was evaluated in accordance to ASTM D5334 [45] by making use of a thermal needle probe ( $60 \mathrm{~mm}$ long and $3.9 \mathrm{~mm}$ in diameter), which was successfully used in previous investigations carried out by the authors $[13,14]$. Tests were performed by drilling three holes on the top surface of cured cylindrical specimens (diameter $100 \mathrm{~mm}$, height $200 \mathrm{~mm}$ ), in which the needle probe could be inserted. To avoid any misreading in measurements, drilled holes were preventively filled with a ceramic-based polysynthetic compound that provided the needle probe 
with the necessary continuous contact with the surrounding mixture. Thermal conductivity was calculated by means of the following expression (Equation (2)):

$$
\mathrm{k}=\frac{\mathrm{q}}{4 \cdot \pi \cdot \mathrm{a}}
$$

where $\mathrm{k}$ is the thermal conductivity (in $\mathrm{W} /(\mathrm{m} \cdot \mathrm{K})$ ), q represents the heating power of the needle, and a indicates the slope of the linear function that describes temperature as a function of the logarithm of time.

Thermal conductivity was measured after 18 days of curing at room temperature, when it was considered that the FTB mixtures would reach conditions that are representative of those ordinarily met in the field. After carrying out the above-described tests, specimens were oven-dried at $60^{\circ} \mathrm{C}$ for $48 \mathrm{~h}$ in order to reach low-moisture conditions, hereinafter referred to as "lab-dried", that mimic those that may occur in service as a consequence of possible drying phenomena due to the heat generated by buried cables. Thermal conductivity tests were repeated on all specimens in lab-dried conditions.

Resilient modulus $\left(\mathrm{M}_{\mathrm{r}}\right)$ tests were carried out on slender cylindrical specimens (diameter $100 \mathrm{~mm}$, height $200 \mathrm{~mm}$ ) after 7 days of curing. Given the low cement contents adopted for the preparation of the FTB mixtures, such a curing period was considered to be sufficient for the development of most of the time-dependent hardening phenomena occurring in service and therefore adequate for the assessment of the long-term bearing capacity of these materials. The $\mathrm{M}_{\mathrm{r}}$ test is commonly employed for the evaluation of the stress-strain response of granular materials under the effects of traffic loading [46-52]. However, it has also been used successfully for the assessment of the mechanical behavior of cement-treated and cold-recycled bituminous mixtures [51-54].

As prescribed by AASHTO T307-99 [55], $\mathrm{M}_{\mathrm{r}}$ tests were carried out by means of a triaxial apparatus that allows the simultaneous control of confining pressure $\left(\sigma_{3}\right)$, which is kept constant, and of deviatoric stress applied in the vertical direction $\left(\sigma_{\mathrm{d}}\right)$, which has a haversine-shaped form. Resulting vertical strains $\left(\varepsilon_{1}\right)$, of a reversible and permanent nature $\left(\varepsilon_{1 \mathrm{r}}\right.$ and $\varepsilon_{1 \mathrm{p}}$, respectively), were measured by means of a pair of LVDTs (Linear Variable Displacement Transducer). According to the adopted standard, test specimens were subjected to 15 loading sequences composed of 100 cycles with various combinations of $\sigma_{3}$ and $\sigma_{\mathrm{d}}$. Then, $\mathrm{M}_{\mathrm{r}}$ values were calculated by using the following expression (Equation (3)):

$$
\mathrm{M}_{\mathrm{r}}=\frac{\sigma_{\mathrm{d}}}{\varepsilon_{1 \mathrm{r}}}
$$

After completion of the thermal and mechanical tests, specimens were crushed by making use of a ball mill in order to obtain a powder suitable to be subjected to the same chemical analyses and leaching tests previously carried out on sludge samples (see Section 2.1).

\section{Results and Discussion}

\subsection{Thermal Properties}

Results of thermal conductivity tests carried out on the FTB mixtures in the two previously described curing conditions are given in Table 8. Listed values were calculated as the average of the results obtained in individual holes drilled in the specimens.

The results displayed in Table 8 clearly indicate that cement content has a significant effect on thermal conductivity. In fact, by increasing cement content from 50 to $100 \mathrm{~kg} / \mathrm{m}^{3}$, a corresponding non-negligible increase of $\mathrm{k}$ was obtained in both curing conditions and for mixtures containing both types of sludge. Such a variation is due to the thermal conductivity of the products formed during the hydration process of cement and to the porosity reduction induced by making use of higher cement dosages $[14,18,19,56,57]$. 
Table 8. Thermal conductivity of FTB mixtures.

\begin{tabular}{ccc}
\hline \multirow{2}{*}{ FTB Mixture } & \multicolumn{2}{c}{ Thermal Conductivity, $\mathbf{k}$} \\
\cline { 2 - 3 } & \multicolumn{2}{c}{$[\mathbf{W} /(\mathbf{m} \cdot \mathbf{K})]$} \\
\cline { 2 - 3 } & 18 Days of Curing & Lab-Dried \\
\hline A-C50-0.85 & 0.97 & 0.51 \\
A-C100-0.75 & 1.57 & 1.04 \\
B-C50-0.75 & 1.16 & 0.84 \\
B-C100-0.75 & 1.70 & 1.15 \\
\hline
\end{tabular}

By analyzing the data in Table 8, effects related to the type of sludge can also be appreciated, especially at the lowest cement content, as a function of the different chemical composition and quartz content of its constituent. In particular, it can be observed that FTB mixtures prepared with sludge B, which has a higher quartz content that sludge A, showed enhanced thermal properties. Such an outcome is consistent with the improved thermal characteristics of quartz [11] and may also be attributed to the different thermal conductivities and concentration of heavy metals contained in this sludge.

As a result of residual moisture loss, a decrease of $k$ was recorded for all FTB mixtures when passing from the conditions associated to 18 days of curing to those reached by means of laboratory drying. By comparing the two sets of data, it is possible to assess the so-called thermal stability of the considered mixtures. This consists in their aptitude to maintain a sufficiently high value of $k$, even in the presence of long-term dry out phenomena. All mixtures exhibited a residual thermal conductivity (i.e., in lab-dried conditions) greater that $50 \%$ of the reference value corresponding to 18 days of curing. The percentages of residual thermal conductivity were similar, of the order of $66-67 \%$, for the two FTB mixtures prepared with higher cement content $\left(100 \mathrm{~kg} / \mathrm{m}^{3}\right)$ regardless of sludge type. On the contrary, when considering the FTB mixtures with the lower cement content $\left(50 \mathrm{~kg} / \mathrm{m}^{3}\right)$, the residual thermal conductivity recorded for the material containing sludge B (equal to $72 \%$ ) was higher than that of the mixture containing sludge A (equal to $52 \%$ ). Such a result is consistent with the general finding that sludge $B$, as a result of its composition, leads to enhanced thermal characteristics.

In order to perform an overall assessment of the effectiveness of employing sawing sludge in FTB mixtures, obtained results were compared to typical $\mathrm{k}$ values reported in the literature for backfilling materials. Although significant variations may occur as a function of particle mineralogy, water content, and degree of compaction, values considered in ampacity calculations for standard backfilling soils, in the absence of any dry-out phenomena, are comprised in the $0.5-1.0 \mathrm{~W} /(\mathrm{m} \cdot \mathrm{K})$ range [2]. As indicated in Table 8, all considered FTB mixtures higher values, comprised between 0.97 and $1.70 \mathrm{~W} /(\mathrm{m} \cdot \mathrm{K})$. Furthermore, thermal conductivity values recorded in lab-dried conditions were consistent with those reported by Choorackal et al. $[13,14]$ for similar FTB mixtures containing various types of fine fractions. It can be thereby postulated that the remarkable thermal properties of the considered FTB mixtures derive from the distribution throughout their structure of sludge particles that possess a significant heat transfer capacity due to their silicate nature and to the presence of heavy metals.

\subsection{Mechanical Properties}

Results obtained from $\mathrm{M}_{\mathrm{r}}$ tests performed on the FTB mixtures after 7 days of curing are reported in Figure 2, where they are plotted as a function of the first stress invariant $(\theta)$. Such a parameter provides a quantification of the global level of stress to which materials are subjected during testing, and it has been found to greatly affect recorded values of $\mathrm{M}_{\mathrm{r}}$ [46]. In Figure 2, experimental data are also compared to the typical variation range indicated by Huang for standard granular sub-bases [58]. 


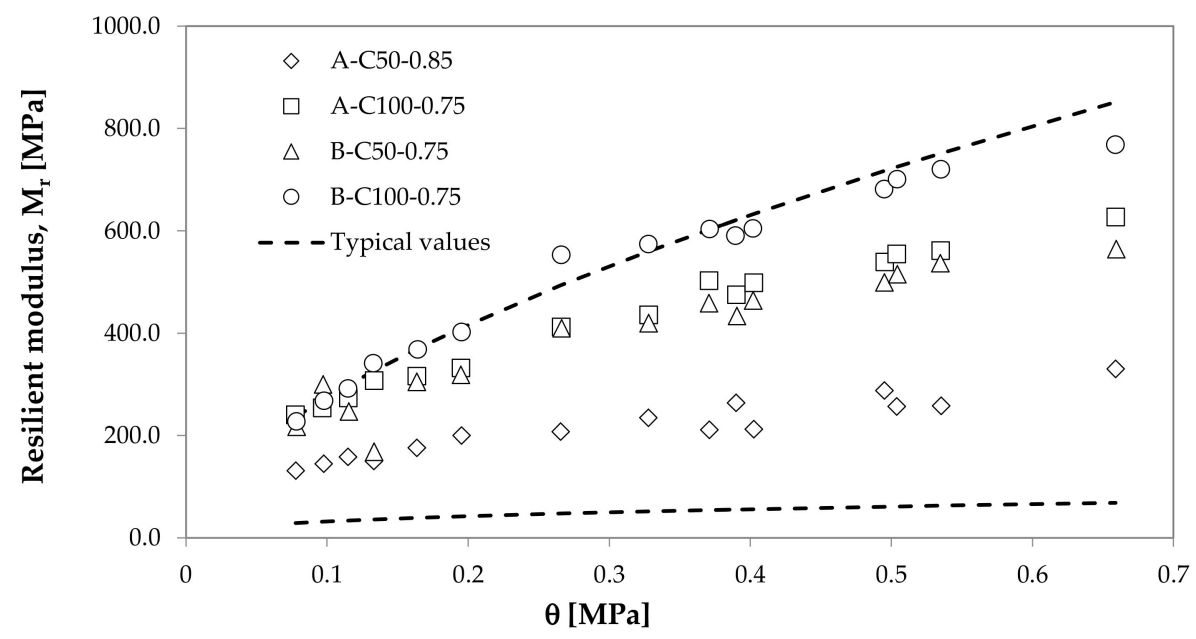

Figure 2. Results of $\mathrm{M}_{\mathrm{r}}$ tests performed after 7 days of curing (all FTB mixtures).

Experimental data plotted in Figure 2 indicate that all the investigated FTB mixtures exhibited a stress-stiffening behavior, with $M_{r}$ values increasing as a function of increasing values of $\theta$. As expected, the FTB mixtures with the higher cement content $\left(100 \mathrm{~kg} / \mathrm{m}^{3}\right)$ displayed a higher stiffness than those with the lower cement content $\left(50 \mathrm{~kg} / \mathrm{m}^{3}\right)$. Recorded $\mathrm{M}_{\mathrm{r}}$ values were significantly higher than those normally reported for pavement subgrades (of the order of 100-200 MPa). It was also observed that with the exception of one of the mixtures with the lower cement content (mixture AC-C50-0.85), most of the displayed $\mathrm{M}_{\mathrm{r}}$ were close to the upper limit of the reference variation range. This finding confirms that the considered FTB mixtures possess mechanical properties that are adequate with respect to their intended use, and they are in fact superior to most of the commonly employed subgrade and sub-base materials.

A comparison between FTB mixtures containing different types of sludge (A and B) is provided in Figure 3, in which $\mathrm{M}_{\mathrm{r}}$ values are plotted as a function of $\theta$ on a $\log$-log scale. The two displayed charts separately refer to mixtures prepared with the same cement content (equal to either 50 or to $100 \mathrm{~kg} / \mathrm{m}^{3}$ ).

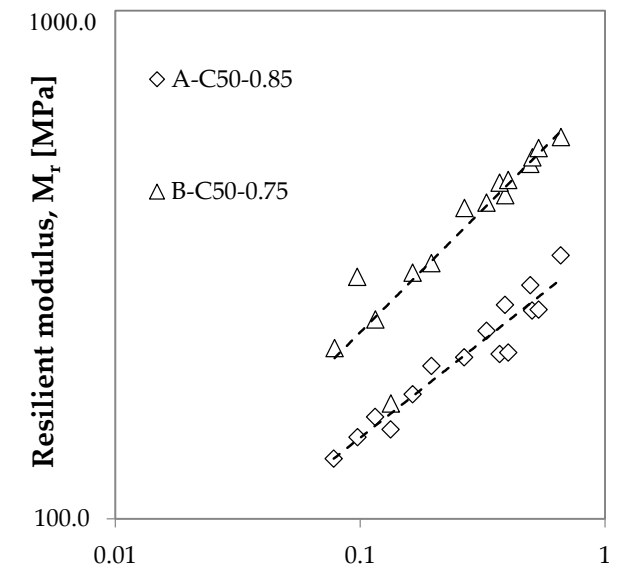

(a)

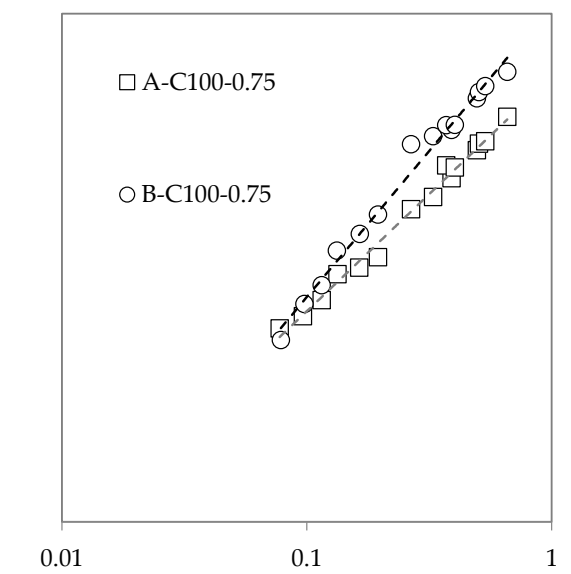

(b)

Figure 3. Results of $\mathrm{M}_{\mathrm{r}}$ tests performed after 7 days of curing: (a) FTB mixtures with cement content $50 \mathrm{~kg} / \mathrm{m}^{3}$; (b) FTB mixtures with cement content $100 \mathrm{~kg} / \mathrm{m}^{3}$.

From the analysis of Figure 3, it can be observed that the FTB mixtures prepared by employing sludge $B$ exhibited at all stress levels a higher stiffness (i.e., a higher $\mathrm{M}_{\mathrm{r}}$ value) than those containing sludge A. It was also found that greater differences were recorded at the lower cement dosage $\left(50 \mathrm{~kg} / \mathrm{m}^{3}\right)$. Such an outcome can be explained by referring to the high quartz content and specific mineralogical composition of sludge B, which probably had a non-negligible influence on cement hydration processes 
and on the resulting calcium-silicate hydrates. Furthermore, it can be postulated that these effects were of reduced intensity when considering a higher cement content $\left(100 \mathrm{~kg} / \mathrm{m}^{3}\right)$, since in this case, cement paste hydration became predominant with respect to other interfering phenomena or reactions.

\subsection{Environmental Properties}

Results of chemical analyses and leaching tests carried out on samples of FTB mixtures obtained by crushing previously prepared specimens are reported in Tables 9 and 10, respectively. As in the case of tests performed on sludge, experimental results are compared to thresholds indicated in current Italian regulations.

Table 9. Chemical composition of FTB mixtures (threshold limits defined in [41], values in mg/kg).

\begin{tabular}{cccccccccccc}
\hline FTB Mixture & Ba & $\mathbf{C u}$ & $\mathbf{Z n}$ & $\mathbf{C o}$ & $\mathbf{N i}$ & $\mathbf{V}$ & $\mathbf{C d}$ & $\mathbf{C r}_{\text {tot }}$ & $\mathbf{C r V I}$ & $\mathbf{P b}$ & $\mathbf{F e}$ \\
\hline A-C50-0.85 & 24 & 11 & 11 & 9 & 4 & 9 & $<1$ & 63 & $<5$ & 2 & 5.120 \\
A-C100-0.75 & 27 & 13 & 12 & 10 & 6 & 10 & $<1$ & 13 & $<5$ & 2 & 6.993 \\
B-C50-0.75 & 29 & 9 & 10 & 2 & 7 & 7 & $<1$ & 11 & $<5$ & 1 & 4.045 \\
B-C100-0.75 & 26 & 15 & 17 & 3 & 11 & 13 & $<1$ & 17 & $<5$ & 2 & 3.990 \\
Threshold limits for reuse & - & 600 & 1500 & 250 & 500 & - & 15 & 800 & 15 & 1000 & - \\
\hline
\end{tabular}

Table 10. Results of leaching tests performed on FTB mixtures (threshold limits defined in [43]).

\begin{tabular}{cccccccccccc}
\hline \multirow{2}{*}{ FTB Mixture } & $\mathbf{B a}$ & $\mathbf{C u}$ & $\mathbf{Z n}$ & $\mathbf{C o}$ & $\mathbf{N i}$ & $\mathbf{V}$ & $\mathbf{C d}$ & $\mathbf{C r}_{\text {tot }}$ & $\mathbf{C r V I}$ & $\mathbf{P b}$ & $\mathbf{F e}$ \\
\cline { 2 - 12 } & {$[\mathbf{m g} / \mathbf{L}]$} & {$[\mathrm{mg} / \mathrm{L}]$} & {$[\mathrm{mg} / \mathrm{L}]$} & {$[\mathrm{g} / \mathrm{L}]$} & {$[\mathrm{g} / \mathrm{L}]$} & {$[\mathrm{g} / \mathrm{L}]$} & {$[\mathrm{g} / \mathrm{L}]$} & {$[\mathrm{g} / \mathrm{L}]$} & {$[\mathrm{g} / \mathrm{L}]$} & {$[\mathrm{g} / \mathrm{L}]$} & {$[\mathrm{mg} / \mathrm{L}]$} \\
\hline A-C50-0.85 & $<0.01$ & $<0.001$ & $<0.001$ & $<1$ & $<1$ & 7.5 & $<1$ & 49.6 & 0.04 & $<1$ & 51.9 \\
A-C100-0.75 & $<0.01$ & $<0.001$ & $<0.001$ & 4 & $<1$ & $<1$ & $<1$ & 62.1 & 0.05 & $<1$ & 30.6 \\
B-C50-0.75 & $<0.01$ & $<0.001$ & $<0.001$ & $<1$ & $<1$ & 2.2 & $<1$ & 94.9 & 0.08 & $<1$ & 49.5 \\
B-C100-0.75 & 0.03 & $<0.001$ & $<0.001$ & $<1$ & $<1$ & $<1$ & $<1$ & 84.9 & 0.06 & $<1$ & 13.3 \\
Threshold limits for reuse & 1 & 0.05 & 3 & 250 & 10 & 250 & 5 & 50 & - & 50 & - \\
\hline
\end{tabular}

The chemical analysis data listed in Table 9 revealed that all considered FTB mixtures exhibited concentrations of heavy metals that were below threshold limits indicated for use in industrial and commercial contexts. Less encouraging results were obtained from leaching tests (Table 10), which highlighted the existence of $\mathrm{Cr}_{\text {tot }}$ concentrations above the maximum allowable limit. Quite surprisingly, recorded values were higher than those measured on the corresponding sludge samples (see Table 5), thus disproving the concept of heavy metal stabilization that has been referred to by several researchers who have described the immobilization effect produced by cement paste $[59,60]$. However, such an outcome may also be explained by considering the possible presence of chromium in cement, as suggested by various studies published in the literature [61-65]. In any case, this specific outcome of the investigation deserves to be addressed in more detail in future investigations before any full-scale application can take place.

\section{Conclusions}

The experimental investigation described in this paper analyzed the feasibility of including sawing sludge in mixtures employed for the formation of Fluidized Thermal Backfills (FTBs). Sawing sludge of two different types was considered and subjected to a thorough preliminary characterization. FTB mixtures containing the two types of sludge and prepared according to a previously developed mix design procedure were characterized in terms of their thermal, mechanical, and environmental properties.

The outcomes of the investigation were extremely positive with respect to thermal and mechanical properties. In particular, it was found that the use of sawing sludge was compatible with the achievement of adequate temperature conductivity and stiffness characteristics, which were found to be superior to those of materials commonly employed for backfilling operations around buried electrical high-voltage cables. Furthermore, it was possible to discriminate between the effects produced by 
the two types of sludge, hypothesizing the mechanisms that lead to different resilient modulus and thermal conductivity values.

With respect to environmental properties, obtained results were partially negative in the specific case of leaching tests, since current Italian legal limits that define reuse conditions were violated. Such an outcome, which is not consistent with the results of leaching tests carried out on sawing sludge, may be due either to the presence of an excessive quantity of wear and tear residues coming from cutting tools or to the chromium content of cement. Nevertheless, further investigations need to be carried out in order to support this explanation. Furthermore, a Life-Cycle Assessment (LCA) analysis of the proposed FTB mixtures is deemed necessary to highlight their impact on the environment in terms of energy and water consumption, and the release of $\mathrm{CO}_{2}$ emissions in order to emphasize the environmental-related benefits of reusing the sawing sludges.

Author Contributions: Conceptualization, L.Z., E.C., M.A. and P.P.R.; methodology, E.C. and P.P.R.; investigation, L.Z., E.C. and M.A.; resources, R.B. and E.S.; data curation, L.Z., E.C., P.P.R. and R.B.; writing-original draft preparation, L.Z., E.C., P.P.R. and R.B.; writing-review and editing, L.Z., E.C., P.P.R., R.B. and E.S.; supervision, P.P.R., R.B. and E.S. All authors have read and agreed to the published version of the manuscript.

Funding: This research received no external funding.

Conflicts of Interest: The authors declare no conflict of interest.

\section{References}

1. Gouda, O.E.; Osman, G.; Salem, W.; Arafa, S.H. Cyclic Loading of Underground Cables Including the Variations of Backfill Soil Thermal Resistivity and Specific Heat with Temperature Variation. IEEE Trans. Power Deliv. 2018, 33, 3122-3129. [CrossRef]

2. Rerak, M.; Ocłoń, P. Thermal analysis of underground power cable system. J. Therm. Sci. 2017, 26, 465-471. [CrossRef]

3. Ocłoń, P.; Cisek, P.; Pilarczyk, M.; Taler, D. Numerical simulation of heat dissipation processes in underground power cable system situated in thermal backfill and buried in a multilayered soil. Energy Convers. Manag. 2015, 95, 352-370. [CrossRef]

4. Fu, C.-Z.; Si, W.-R.; Quan, L.; Yang, J. Numerical Study of Heat Transfer in Trefoil Buried Cable with Fluidized Thermal Backfill and Laying Parameter Optimization. Math. Probl. Eng. 2019, 2019, 1-13. [CrossRef]

5. Gouda, O.E.; El Dein, A.Z. Improving underground power distribution capacity using artificial backfill materials. IET Gener. Transm. Distrib. 2015, 9, 2180-2187. [CrossRef]

6. Ocłoń, P.; Cisek, P.; Taler, D.; Pilarczyk, M.; Szwarc, T. Optimizing of the underground power cable bedding using momentum-type particle swarm optimization method. Energy 2015, 92, 230-239. [CrossRef]

7. Quan, L.; Fu, C.; Si, W.; Yang, J.; Wang, Q. Numerical study of heat transfer in underground power cable system. Energy Procedia 2019, 158, 5317-5322. [CrossRef]

8. Williams, J.A.; Parmar, D.; Conroy, M.W. Controlled backfill optimization to achieve high ampacities on transmission cables. IEEE Trans. Power Deliv. 1994, 9, 544-552. [CrossRef]

9. Rao, M.G.; Kolay, P.; Singh, D. Thermal characteristics of a class F fly ash. Cem. Concr. Res. 1998, 28, 841-846. [CrossRef]

10. Kolay, P.K.; Singh, D. Application of Coal Ash in Fluidized Thermal Beds. J. Mater. Civ. Eng. 2002, 14, 441-444. [CrossRef]

11. Célestin, J.C.H.; Fall, M. Thermal conductivity of cemented paste backfill material and factors affecting it. Int. J. Min. Reclam. Environ. 2009, 23, 274-290. [CrossRef]

12. Bascom, E.C.R.; Patel, N.; Parmar, D. Thermal Environment Design Considerations for Ampacity of Buried Power Cables. In Proceedings of the IEEE Transmission \& Distribution Conference, Chicago, IL, USA, 14-16 April 2014.

13. Choorackal, E.A.; Riviera, P.P.; Dalmazzo, D.; Santagata, E.; Zichella, L.; Marini, P. Reuse of Recycled Asphalt Pavement and Mineral Sludges in Fluidized Thermal Backfills. In Proceedings of the 6th International Conference on Sustainable Solid Waste Management, Naxos Island, Greece, 13-16 June 2018. 
14. Choorackal, E.; Riviera, P.P.; Dalmazzo, D.; Santagata, E.; Zichella, L.; Marini, P. Performance-Related Characterization of Fluidized Thermal Backfills Containing Recycled Components. Waste Biomass Valoris. 2019, 11, 5393-5404. [CrossRef]

15. Choorackal, E.; Riviera, P.P.; Santagata, E. Mix design and mechanical characterization of self-compacting cement-bound mixtures for paving applications. Constr. Build. Mater. 2019, 229, 116894. [CrossRef]

16. Riviera, P.P.; Bertagnoli, G.; Choorackal, E.; Santagata, E. Controlled low-strength materials for pavement foundations in road tunnels: Feasibility study and recommendations. Mater. Struct. 2019, 52, 72. [CrossRef]

17. Kim, K.-H.; Jeon, S.-E.; Kim, J.-K.; Yang, S. An experimental study on thermal conductivity of concrete. Cem. Concr. Res. 2003, 33, 363-371. [CrossRef]

18. Uysal, H.; Demirboğa, R.; Şahin, R.; Gül, R. The effects of different cement dosages, slumps, and pumice aggregate ratios on the thermal conductivity and density of concrete. Cem. Concr. Res. 2004, 34, 845-848. [CrossRef]

19. Damdelen, O. Influences of construction material type and water-cement ratio reduction on thermal transmittance of sustainable concrete mixes. Constr. Build. Mater. 2019, 196, 345-353. [CrossRef]

20. Graziani, A.; Giovannelli, G. I Lapidei. Struttura del Settore e Tendenze Innovative; Centro Studi Osservatorio Fillea: Rome, Italy, 2015.

21. Zichella, L.; Bellopede, R.; Spriano, S.; Marini, P. Preliminary investigations on stone cutting sludge processing for a future recovery. J. Clean. Prod. 2018, 178, 866-876. [CrossRef]

22. Careddu, N.; Dino, G. Reuse of residual sludge from stone processing: Differences and similarities between sludge coming from carbonate and silicate stones-Italian experiences. Environ. Earth Sci. 2016, 75. [CrossRef]

23. Chouhan, H.S.; Kalla, P.; Nagar, R.; Gautam, P.K. Influence of dimensional stone waste on mechanical and durability properties of mortar: A review. Constr. Build. Mater. 2019, 227, 116662. [CrossRef]

24. Zichella, L.; Dino, G.A.; Bellopede, R.; Marini, P.; Padoan, E.; Passarella, I. Environmental impacts, management and potential recovery of residual sludge from the stone industry: The piedmont case. Resour. Policy 2020, 65, 101562. [CrossRef]

25. Hamaie, H.D.A.; Khushefati, W.H. Granite Sludge Reuse in Mortar and Concrete. J. Appl. Sci. 2013, 13, 444-450. [CrossRef]

26. Amin, M.N.; Khan, K.; Saleem, M.U.; Khurram, N.; Niazi, M.U.K. Aging and Curing Temperature Effects on Compressive Strength of Mortar Containing Lime Stone Quarry Dust and Industrial Granite Sludge. Materials 2017, 10, 642. [CrossRef] [PubMed]

27. Mashaly, A.O.; Shalaby, B.N.; Rashwan, M. Performance of mortar and concrete incorporating granite sludge as cement replacement. Constr. Build. Mater. 2018, 169, 800-818. [CrossRef]

28. Singh, S.; Khan, S.; Khandelwal, R.; Chugh, A.; Nagar, R. Performance of sustainable concrete containing granite cutting waste. J. Clean. Prod. 2016, 119, 86-98. [CrossRef]

29. Singh, S.; Nande, N.; Bansal, P.; Nagar, R. Experimental Investigation of Sustainable Concrete Made with Granite Industry By-Product. J. Mater. Civ. Eng. 2017, 29, 04017017. [CrossRef]

30. Da Silva, J.L.; Campos, D.B.D.C.; Lordsleem, A.C.; Povoas, Y.V. Influence of the partial substitution of fine aggregate by granite powder in mortar on the process of natural carbonation. Waste Manag. Res. 2019, 38, 254-262. [CrossRef]

31. Santagata, E.; Baglieri, O.; Tsantilis, L.; Chiappinelli, G.; Riviera, P.P. Re-Use in Asphalt Pavements of Fillers from Natural Stone Sawmilling Sludge. In Proceedings of the AIIT International Congress on Transport Infrastructure and Systems (TIS 2017), Rome, Italy, 10-12 April 2017. [CrossRef]

32. Aydin, E.; Arel, H.Ş. High-volume marble substitution in cement-paste: Towards a better sustainability. J. Clean. Prod. 2019, 237, 237. [CrossRef]

33. EN 197-1. Cement-Part 1: Composition, Specifications and Conformity Criteria for Common Cements. Available online: https://standards.globalspec.com/std/1399038/EN\%20197-1 (accessed on 4 November 2017).

34. Khan, M. Factors affecting the thermal properties of concrete and applicability of its prediction models. Build. Environ. 2002, 37, 607-614. [CrossRef]

35. Balkan, E.; Erkan, K.; Şalk, M. Thermal conductivity of major rock types in western and central Anatolia regions, Turkey. J. Geophys. Eng. 2017, 14, 909-919. [CrossRef] 
36. EN 933-1. Tests for Geometrical Properties of Aggregates-Part 1: Determination of Particle Size Distribution-Sieving Method. Available online: https://standards.iteh.ai/catalog/standards/cen/100b983f85a4-4a80-934c-e93c584dbdb4/en-933-1-2012 (accessed on 4 November 2017).

37. EN 1097-6. Tests for Mechanical and Physical Properties of Aggregates_Part 6: Determination of Particle Density and Water Absorption. Available online: https://standards.iteh.ai/catalog/standards/cen/efd7df30eac1-4445-90eb-9b2958fb2564/en-1097-6-2013 (accessed on 4 November 2017).

38. EPA. EPA 3051A and EPA 6020A. 2007. Available online: https://www.epa.gov/sites/production/files/201507/documents/epa-6020a.pdf (accessed on 5 November 2017).

39. EN 12457-2. Characterisation of waste-Leaching-Compliance Test for Leaching of Granular Waste Materials and Sludges_-Part 2: One Stage Batch Test at a Liquid to Solid Ratio of 10 1/kg for Materials with Particle Size below $4 \mathrm{~mm}$ (without or with Size Reduction). Available online: https://standards.iteh.ai/catalog/ standards/cen/db6fbdf3-1de7-457c-a506-46c4898e3f09/en-12457-2-2002 (accessed on 4 November 2017).

40. Ali, S.E.; Ako, T.A. Lk+petrographic and physic-mechanical characteristics of quartzite from the wolframite mine in Zumba, northcentral Nigeria: implication for their use as construction materials. J. Appl. Geol. Geophys. 2018, 6, 59-76. [CrossRef]

41. Decreto Ministeriale 5 Febbraio 1998. Individuazione dei rifiuti non pericolosi sottoposti alle procedure semplificate di recupero ai sensi degli articoli 31 e 33 del decreto legislativo 5 febbraio 1997, n. 22, (GU Serie Generale n.88 del 16-04-1998-Suppl. Ordinario n. 72) (in Italian).

42. Decreto Legislativo 3 Aprile 2006, n. 152. Norme in materia ambientale. (GU Serie Generale n.88 del 14-04-2006-Suppl. Ordinario n. 96).

43. Decreto Ministeriale 5 Aprile 2006, n. 186. Regolamento recante modifiche al decreto ministeriale 5 febbraio 1998 “Individuazione dei rifiuti non pericolosi sottoposti alle procedure semplificate di recupero, ai sensi degli articoli 31 e 33 del decreto legislativo 5 febbraio 1997, n. 22" (GU Serie Generale n.115 del 19-05-2006) (in Italian).

44. Funk, J.E.; Dinger, D.R. Predictive Process Control of Crowded Particulate Suspensions; Springer: New York, NY, USA, 1994.

45. ASTM. Standard Test Method for Determination of Thermal Conductivity of Soil and Soft Rock by Thermal Needle Probe Procedure; ASTM D5334-14; ASTM: West Conshohocken, PA, USA, 2014.

46. Lekarp, F.; Isacsson, U.; Dawson, A. State of the Art. I: Resilient Response of Unbound Aggregates. J. Transp. Eng. 2000, 126, 66-75. [CrossRef]

47. Riviera, P.P.; Bellopede, R.; Marini, P.; Bassani, M. Performance-based re-use of tunnel muck as granular material for subgrade and sub-base formation in road construction. Tunn. Undergr. Space Technol. 2014, 40, 160-173. [CrossRef]

48. Pratibha, R.; Babu, G.L.S.; Latha, G.M. Stress-Strain Response of Unbound Granular Materials Under Static and Cyclic Loading. Indian Geotech. J. 2015, 45, 449-457. [CrossRef]

49. Bilodeau, J.-P.; Ouellet-Plamondon, C.; Doré, G. Estimation of resilient modulus of unbound granular materials used as pavement base: Combined effect of grain-size distribution and aggregate source frictional properties. Mater. Struct. 2016, 49, 4363-4373. [CrossRef]

50. Bassani, M.; Riviera, P.P.; Tefa, L.; Chiappinelli, G. Effects of quantity and plasticity of fine particles on the workability and resilient behaviour of aggregate-soil mixtures for granular pavement layers. Road Mater. Pavement Des. 2019, 1-20. [CrossRef]

51. Taha, R.; Al-Harthy, A.; Al-Shamsi, K.; Al-Zubeidi, M. Cement Stabilization of Reclaimed Asphalt Pavement Aggregate for Road Bases and Subbases. J. Mater. Civ. Eng. 2002, 14, 239-245. [CrossRef]

52. Santagata, E.; Chiappinelli, G.; Riviera, P.P.; Baglieri, O. Triaxial Testing for the Short Term Evaluation of Cold-Recycled Bituminous Mixtures. Road Mater. Pavement Des. 2010, 11, 123-147. [CrossRef]

53. Fatemi, S.; Imaninasab, R. Performance evaluation of recycled asphalt mixtures by construction and demolition waste materials. Constr. Build. Mater. 2016, 120, 450-456. [CrossRef]

54. Bassani, M.; Riviera, P.P.; Tefa, L. Short-Term and Long-Term Effects of Cement Kiln Dust Stabilization of Construction and Demolition Waste. J. Mater. Civ. Eng. 2017, 29, 04016286. [CrossRef]

55. AASHTO. Standard Method of Test for Determining the Resilient Modulus of Soils and Aggregate Materials; AASHTO T 307-99; AASHTO: Washington, DC, USA, 2003.

56. Lo-Shu, K.; Man-Qing, S.; Xing-Sheng, S.; Yun-Xiu, L. Research on several physico-mechanical properties of lightweight aggregate concrete. Int. J. Cem. Compos. Light. Concr. 1980, 2, 185-191. [CrossRef] 
57. Mengistu, A.G.; Van Rensburg, L.D.; Mavimbela, S.S. The effect of soil water and temperature on thermal properties of two soils developed from aeolian sands in South Africa. Catena 2017, 158, 184-193. [CrossRef]

58. Huang, Y.H. Pavement Analysis and Design, 2nd ed.; Pearson Education Inc.: Upper Saddle River, NJ, USA, 2004.

59. Poon, C.; Clark, A.; Peters, C.; Perry, R. Mechanisms of Metal Fixation and Leaching by Cement Based Fixation Processes. Waste Manag. Res. 1985, 3, 127-142. [CrossRef]

60. Huang, M.; Feng, H.; Shen, D.-S.; Li, N.; Chen, Y.; Shentu, J. Leaching Behavior of Heavy Metals from Cement Pastes Using a Modified Toxicity Characteristic Leaching Procedure (TCLP). Bull. Environ. Contam. Toxicol. 2016, 96, 354-360. [CrossRef] [PubMed]

61. Rojas, M.F.; De Rojas, M. Total and soluble chromium, nickel and cobalt content in the main materials used in the manufacturing of Spanish commercial cements. Cem. Concr. Res. 2002, 32, 435-440. [CrossRef]

62. Potgieter, S.; Panichev, N.; Potgieter, J.; Panicheva, S. Determination of hexavalent chromium in South African cements and cement-related materials with electrothermal atomic absorption spectrometry. Cem. Concr. Res. 2003, 33, 1589-1593. [CrossRef]

63. Laforest, G.; Duchesne, J. Immobilization of chromium (VI) evaluated by binding isotherms for ground granulated blast furnace slag and ordinary Portland cement. Cem. Concr. Res. 2005, 35, 2322-2332. [CrossRef]

64. Estokova, A.; Palascakova, L.; Singovszka, E.; Holub, M. Analysis of the Chromium Concentrations in Cement Materials. Procedia Eng. 2012, 42, 123-130. [CrossRef]

65. Estokova, A.; Palaščáková, L.; Kanuchova, M. Study on Cr (VI) Leaching from Cement and Cement Composites. Int. J. Environ. Res. Public Health 2018, 15, 824. [CrossRef]

Publisher's Note: MDPI stays neutral with regard to jurisdictional claims in published maps and institutional affiliations. 